\title{
Research on the Individual Talent Training Mode
}

\author{
Baiyi $\mathrm{An}^{1 \mathrm{a}}$ and Wei Shen $\mathrm{b}^{\mathrm{k}}$ \\ ${ }^{1}$ College of Horticulture, Jilin Agricultural University, Jilin, China \\ ${ }^{2}$ College of Computer Science and Technology,Beihua University,Jilin, China \\ aswabyswaby@163.com, ${ }^{\mathrm{b}}$ abyswabysw@163.com
}

Keywords: Individualization; Talent Training Mode; Higher education

\begin{abstract}
Through the implementation of training innovative talents innovation strategy is the consensus of the world knowledge economy era. Local colleges and universities is the important base of training innovative talents, local colleges of undergraduate course education in the basic position in cultivating innovative talents. To improve the quality of undergraduate education, we must to undergraduate talents training mode reform and innovation. Talent training quality in colleges and universities in recent years, our country society more and more, the level of criticism as countries continuously intensify of undergraduate talent training mode reform, realize that only by promoting the harmonious development of the personality education can really promote the development of society, many local colleges began to actively explore building personalized training mode, under this background, the research on personalized training mode, has important theory value and practical significance.
\end{abstract}

\section{Introduction}

At present, our country's higher education is in a critical period of from scale expansion to improve the quality. With the enlargement of the scale of higher education, student groups appeared the trend of diversification, students' learning interest, learning ability, learning the differences of demand more and more outstanding. Talent supply and demand and the change of the distribution system at the same time, as well as the employment of two-way choice, graduates can work on its own terms. How to adapt to the needs of different students, meet the needs of personal cultivation, is an important breakthrough of cultivating innovative talents. Individualized education has two basic premise, it is to respect students' individual character, the second is to provide and create conditions conducive to the development of students' personality and the environment. We believe that the training of high-level personnel of university education personalized education, the key problems is the training mode should be diversified and flexible, the teaching method should be open and initiative.

\section{Personalization, and Personnel Training Mode}

\section{The Basic Situation of Foreign Talent Cultivation Model}

Respect the student individuality, takes student's subject selection and the individuality expression, is the western developed countries generally implement the training mode of higher education. Will China's institutions of higher learning the talent training scheme compared with similar foreign university, one of the most obvious difference, is the lack of personalization. Many colleges and universities abroad of the organic combination of social needs and individual interests, as the important basis to build innovative talents cultivation model. Engineering colleges in the United States has no unified national professional directory, professional set up diversified. Many school teaching plan in terms of curriculum has a great deal of resiliency, and large amount of courses in the area wide, both general education and professional education, students choice is very big, the students can according to their own ability, interests and aspirations elective courses in the future. Japanese university courses (50\%), French courses was $40 \% \sim 40 \%$, the UK university general second year about $20 \%$ of the courses, the first school year is $50 \%$ of the courses. At Stanford 
university, the school six more than 6000 undergraduate students, for undergraduate courses in the six more than 6000, the average student can enjoy a course independently. Not only can students according to their interests and going to choose professional jobs, and are free to choose courses, so that the students can full of passion to learn and practice, give full play to their personality.

\section{Personal Cultivation Problems in Personnel Training Mode of our Country}

Many colleges and universities in China in recent years has made many attempts, in terms of student personal cultivation such as according to the categories of the recruitment of students, the school turn a major, double major, double major and a minor in professional way, but the results are clear enough.Mainly displays in: one is the project of talent fostering and the curriculum is still more restrictive.Compulsory course represents a significant share, the more class, the proportion of elective courses is far lower than similar foreign universities, the number of courses is too little, provide curriculum choice is limited, made in training plan and curriculum is the lack of choice of freedom, and do not have enough time to elementary;2 it is not a complete credit system, personal cultivation in no time and space on the guarantee to promote large area, therefore had to be carried out in accordance with the unified model training within the prescribed period of time to learn the rules of credit, as a mass culture.

The existence of these problems, not only affects the teaching quality and effect, and also seriously affected the development of students' learning interest, restricted the development of personality. The root of the problem are the following:

The concept of education cannot be adapted to the development of social and economic.Talent cultivation in colleges and universities has long been under the planned economy mode, the average college talent training and the social demand and the consistency of the division of labor has a relative graduates can go to the corresponding jobs can cast.With the development of society and economy, the relative consistency is broken, the talented person's demand is not dominated by the government according to the market changes, so the talented person's demand diversification, the flow of talents increase year by year, talent competition is also increasing. University reform is not completely from the planned economy model, for example, recruit students is goes as planned, training is carried out in accordance with the roughly the same pattern, while graduates need independent career.Because education ideas cannot be adapted to the development of social and economic, on the training programs and courses can't satisfy the social needs of choose and employ persons, talent education lag behind the development of the talent market, lead to college talents training and social needs is not enough coordination between the supply and demand.

The incentive mechanism can't arouse the enthusiasm of the teaching reform.Individuation talents cultivation in the main force is a teacher, need their active exploration, concrete implementation and constantly sum up experience, it is necessary to spend a lot of time and energy.Most schools in our country at present to teacher to post reviews or year-end appraisal way, for the teaching evaluation criteria is to complete the teaching quantity, although the schools also have about the quality of teaching evaluation and implementing measures, but has not really implemented.Some schools for the teaching and research in academic study score is lower than scoring, heavy not heavy teaching research of scientific research, in the teachers' title and all kinds of promotion especially reward assessment activities.As a result, lead to teachers for education teaching the input of energy shortage.Another case is a teacher can get more in the class teaching more workload, many teachers struggle to cope with heavy teaching task, weakening the teaching research.

The teaching environment and condition cannot meet the demand of personal cultivation.In recent years, the schools teaching environment and facilities are greatly improved.But, can satisfy personalized training need not open experiment project, an open experimental project open rate is not high also.There are many school teaching facilities is insufficient, even if the cycle from morning till night, also can maintain the current curriculum plan set, the more difficult to adapt to the personalized training need class, small class discussion teaching requirements.

To Promote the Cultivation Model of Personalized Measures

Personalized training mode should be diversified in the first place. At present our country higher 
education have different positioning of the school, the school also have different positioning in different colleges and positioning of the professional.But, to meet the needs of personal cultivation, even within a professional should have different positioning of the training mode. As in the current common practice to realize even read, on the basis of other diversified training mode, should also be considered to meet the demand of all kinds of talent cultivation, respectively.Students after graduation, should also be considered a modular training mode, such as employment module, examination module, the module to study abroad, etc.For some special professional, can be allowed to set up to meet the requirements of professional curriculum modules and system.At the same time, combining with the characteristics of professional practice the hierarchical teaching, classification, strive to make every student has an appropriate professional development direction, the future development for the students to provide broad space for development.Education departments at all levels should intensify their efforts to support and encourage the diversification of pilot training mode.

Personalized training plan should be flexible. First, push forward the complete credit system, to implement the flexibility of length of schooling, can in some professional pilot or on the basis of the existing materials to promote; Second, reform and optimization of foundation courses and professional course system and teaching content of courses of the main stem, compression required course; Third, increase the proportion of elective courses, and ensure the quality and quantity of elective courses, students are encouraged to according to the needs of society and their own interests and hobbies, across different department of professional course, flexible combination of their own knowledge structure, maximize learning efficiency; Fourth, improve the elasticity under the credit system of student status management system, so that the students can really choose learning time and learning process, to achieve truly customize professional, free length of schooling, optional courses, and customize the teacher.

\section{Personalized Training Mode of Teaching Methods}

Who had to learn experience abroad or had working experience in foreign colleges and universities, will naturally will loose and free study environment abroad and domestic tedious learning atmosphere.One is foreign courses in many universities in the few unified teaching material, the professor taught mostly in their own learning or scientific research as the main teaching content;The second is the independent and interactive teaching method is very common, active atmosphere of tutorials are very common.Often transformation between teachers and students, teachers from the front to the behind the scenes, as supporters of the student activity;Three is the inspection way agile diversity, such as comprehensive, papers to examine the form of the speech, pay attention to the cultivation of students' comprehensive ability.

Our country's higher education has attached great importance to the teaching method of research, especially since the reform and opening up, many times of major education teaching reform project of ministry of education, will be focusing on the research and reform teaching methods, in recent years has achieved some success.However, teaching, research method, the heavy result, light process, the practice of theory, practice is still very serious, and individualized education and innovative talent training requirements. The teaching method of personalized education should be how?

\section{From the perspective of the interest}

The essence of personalized from your interests.Interest is the best teacher, this is known as the topic, but often ignored in the higher education of personal cultivation.How to cultivate students' interest in learning?

Should be good inspiration and interaction design.Heuristic and interactive, though it is a cliche topic, but in what we come into contact with many of the classroom teaching, while the teacher prepares a lesson earnestly, skilled, but class effect is not very good, some students fall a sleep, depressing atmosphere makes people feel to suffocate. The main problem is that teachers lack of passion, lack of inspiration, the lack of interaction and the classroom, can inspire students' interest in learning and personality?Heuristic and interactive teaching is the need to design. The design of 
the teaching content, including how to begin with the problem, how to contact the actual;Design the way of teaching, including how to interact, how to enable students to actively published personal opinion;Multimedia teaching plans or the design of the courseware, from the content, layout, color, font, etc., all need to elaborate on how to stimulate students interest.In short to be a good actor, to cause the audience's interest, it must design a good script.

Should improve teaching art.Teaching activity is expressed through the teachers' language and behavior, so the teacher's words and deeds have a direct impact on the students' interest in learning. Should pay attention to their own charm and the improvement of teaching art, such as appropriate appearance, wonderful language, aplomb itself, concise beautiful blackboard writing skills in solving problems, quick thinking, skilled, etc., will help the interest of students.Students like the teacher, you would like to you teach this course, and gradually became interested in it.

\section{Open teaching}

Open mode teaching methods, one is to break the traditional teaching, promoting the extracurricular reading, let the students understand relevant knowledge in the field of textbooks, more to let students understand the new theory, new method and new technology;The second is to give students a proper freedom, released a personalized view;3 it is the teacher speaks perfect don't put all the knowledge, to leave room for students' self-study and space;Four is to change the topic thesis collection, problem solving method, the problem solving process dull way of after-school exercises, the development can stimulate students' innovation consciousness, give full play to the individual homework and practice training of wisdom, so that the students are thinking and exploration of the lines, personalized get into full play.

Is an important part of higher education practice, and personalized teaching methods, not only to stimulate students interest in the theory of learning and initiative, more important is to advocate active practice, in active practice, students' personality can only be fully made use of, this also is the key to cultivate the innovative ability.

University, especially the key university in our country, attaches great importance to practice, but compared with developed countries of college students, can obviously feel that our students lack personality and method in solving practical problems, therefore, innovative spirit and ability to have a larger gap.There are a variety of causes of the gap, passive practice should be the main reasons. Passive practice refers to the practice of the key elements such as object, method and program are set by the teacher, the students in the framework of the teacher rules, following the teacher set route to complete the practice task.In the path of the basic rules, don't need to play a character and imagination, can complete the task. The practice of higher education in our country, the vast majority are such passive practice.

Active practice is the key to mobilize and inspire the students' interest and desire to practice, let the student practice as real as the main body participation in activities of each link, including the choice of object, the method of making, the design of the program and the question, analysis summary, etc.In the process of active practice, students' question force, such as observation, collaborative force quality can be nurtured, personality play.Active cultivation of practical ability is not only in the production practice and graduation design in such a typical practice link, link in course include basic subjects of learning, also reflect everywhere need active practice.

\section{Conclusion}

Reform practice results show that personalized training mode and ways to encourage students to diversified development, improve the innovation consciousness and can Force is very effective.Some students are very adapt to the teaching reform and innovation potential and innovation consciousness have been greatly inspired;But there are also some students do not adapt to show.Therefore, how to in this kind of open, equality and encourage questions, encourage innovation teaching atmosphere and environment, further deepening and refining, make different starting point, ability, personality of the students are wana find a more suitable scheme is the key to need further study and solve the problem. 


\section{Acknowledgements}

The authors wish to thank the Jilin Province Education Science Planning Project(GH170278)、 (ZD17022) (SJJY201719), under which the present work was possible.

\section{References}

[1] Lucia Naldi,Mattisa Nordqvist.Entrepreneurial Orientation,Risk Taking,and performance in Family Firms[J].Journal of the family firm institute,2007(l):33-47.

[2] Emest L Boyer. Schlarship Reconsidered: Priorities of the Professoriate. Princeton: The Camegie Foundation for the Advancement of Teaching, 1990.

[3] Wallmark J T, McQueen D H, Sedig K Q. Measurement of output from university research, a case study[J]. Engineering Management, IEEE Transactions, 2008, 3:175-180.

[4] Youtie J , Shapira P. Building an innovation hub: a case study of the transformation of university roles in regional technological and economic development[J]. Research Policy, 2008, 37(8): 1188-1204.

[5] Geenhuizen M V, Soetanto D P. Academic spin-offs at different ages: A case study in search of key obstacles to growth[J]. Technovation, 2009, 29(10):671-681.

[6] Fini R, Grimaldi R, Santoni S, et al. Complements or substitutes? The role of universities and local context in supporting the creation of academic spin-offs[J].Research Policy, 2011, 40(8): 1113-1127.

[7] Information on http://www.people.com.cn/GB/32306/33232/14743200.html

[8] Information on http://www.ox.ac.uk/about/oxford - people/famous - oxonians

[9] Anders Lundstrom,Lois Stevenson. Entrepreneurship Policy:Theory and practice[M].New Mexico, Springer, 2005.

[10] Nabi G, et al. From student to entrepreneur: Towards a model of graduate entrepreneurial career-making[J].Journal of Education and Work, 2010,23(5):389-411.

[11] Nabi G, et al. From student to entrepreneur: Towards a model of graduate entrepreneurial career-making[J].Journal of Education and Work, 2010,23(5):389-411.

[12] Youtie J , Shapira P. Building an innovation hub: a case study of the transformation of university roles in regional technological and economic development[J]. Research Policy, 2008, 37(8): 1188-1204.

[13] Wallmark J T, McQueen D H, Sedig K Q. Measurement of output from university research, a case study[J]. Engineering Management, IEEE Transactions, 2008, 3:175-180.

[14]Emest L Boyer. Schlarship Reconsidered: Priorities of the Professoriate. Princeton: The Camegie Foundation for the Advancement of Teaching, 1990.

[15]Fini R, Grimaldi R, Santoni S, et al. Complements or substitutes? The role of universities and local context in supporting the creation of academic spin-offs[J].Research Policy, 2011, 40(8): 1113-1127.

[16] Information on http://www.people.com.cn/GB/32306/33232/14743200.html

[17] Information on http://www.ox.ac.uk/about/oxford - people/famous - oxonians 